\title{
SIKAP DALAM MEMEDIASI HUBUNGAN KESADARAN LINGKUNGAN DENGAN NIAT BELI PRODUK KOSMETIK RAMAH LINGKUNGAN
}

\author{
Nyoman Dara Paramita ${ }^{1}$ dan Ni Nyoman Kerti Yasa ${ }^{1 *}$ \\ ${ }^{1}$ Fakultas Ekonomi dan Bisnis, Universitas Udayana \\ Jalan P. B. Sudirman, Bali 80112, Indonesia \\ *Penulis Korespondensi; Email: manraikerti@yahoo.co.id
}

\begin{abstract}
Abstrak
Tujuan penelitian ini adalah untuk mengetahui peran sikap dalam memediasi hubungan kesadaran lingkungan dengan niat beli produk kosmetik ramah lingkungan merek "The Body Shop" di Denpasar. Jumlah sampel 105 responden, diambil menggunakan teknik purposive sampling. Pengujian dilakukan menggunakan analisis SEM dan uji Sobel. Hasil penelitian menunjukkan bahwa, semakin tinggi kesadaran lingkungan, maka niat beli konsumen untuk membeli produk kosmetik ramah lingkungan merek "The Body Shop" semakin meningkat. Namun sikap konsumen tidak mampu memediasi hubungan antara kesadaran lingkungan dengan niat beli produk kosmetik ramah lingkungan. Hal ini menunjukkan bahwa dengan adanya kesadaran lingkungan yang semakin tinggi tanpa adanya sikap positifpun sudah mampu meningkatkan niat beli konsumen terhadap produk kosmetik ramah lingkungan merek "The Body Shop."
\end{abstract}

Kata kunci: Sikap, kesadaran lingkungan, niat beli

\begin{abstract}
The purpose of this study was to determine the role attitudes to mediate the relationship between environmental awareness with the purchase intention eco-friendly cosmetics "The Body Shop" in Denpasar. Samples taken were 105 respondent, used purposive sampling techniques. This study used SEM analysis and the Sobel Test. The results showed that, the higher the environmental awareness tent to increase purchase intention of consumers to buy eco-friendly cosmetics brand "The Body Shop." However, consumer attitudes did not affect the relationship between environmental awareness with the intention to buy eco-friendly cosmetic products. This suggested that eventhough without any positive consumer attitude. The higher environmental awareness could enhance the purchase intention towards eco-friendly cosmetic products "The Body Shop."
\end{abstract}

Keywords: Attitudes, environmental awareness, purchase intention

\section{Pendahuluan}

Kerusakan-kerusakan lingkungan hidup saat ini sudah semakin parah dan telah memancing keprihatinan yang berakibat pada pemanasan global, penipisan lapisan stratosfir ozon, pencemaran laut dan sungai, kebisingan dan polusi cahaya, hujan asam dan desertifikasi. Kerusakan mengarah kepada degradasi lingkungan, meskipun tidak mencapai tingkatan yang membahayakan, tetapi sudah mencapai pada tingkatan yang menurunkan kualitas bumi sebagai tempat tinggal (Ardianti, Fahmi, \& Ratnawati, 2008). Masalah lingkungan yang utama saat ini adalah penebangan hutan secara liar, polusi air akibat limbah industri, polusi udara di daerah perkotaan, perambahan kawasan konservasi, menurunnya kualitas keanekaragaman hayati (Chen, 2011).

Kondisi lingkungan seperti ini memunculkan kesadaran masyarakat untuk menjaga kelestarian ling- kungan. Didorong oleh kesadaran akan pelestarian lingkungan, masyarakat menuntut produsen tidak hanya memperhatikan atribut pemasaran, seperti harga, kualitas, promosi dan ketersediaan, tetapi juga menuntut produsen peduli terhadap lingkungan (Harris, 2006). Tuntutan yang diminta konsumen kepada produsen adalah adanya kepedulian terhadap proses produksi dari suatu produk serta memperhatikan dampak sosial, kesehatan dan ekologis yang timbul dari produksi, distribusi, konsumsi dan pembuangan suatu produk. Konsumen yang menuntut produsen agar berperilaku seperti itu disebut dengan istilah konsumen hijau.

Konsumen hijau merupakan perilaku pembeli menghindari produk yang membahayakan kesehatannya atau orang lain, menyebabkan kerusakan lingkungan, serta menghindari penggunaan energi dalam jumlah yang tidak sewajarnya sehingga menyebabkan pemborosan dan tidak menggunakan bahan berasal 
dari spesies yang terancam kepunahannya (Arttachariya, 2012). Tuntutan konsumen akan produk yang ramah lingkungan membuat produsen mulai mengubah orientasi usaha. Jika selama ini produsen hanya berorientasi ekonomi semata maka orientasi produsen secara perlahan mulai berubah untuk mempertimbangkan aspek ekologis. Salah satu cara produsen untuk memenuhi kebutuhan dan keinginan konsumen hijau sekaligus untuk menunjukkan tanggung jawab sosialnya terhadap lingkungan adalah dengan menawarkan produk hijau (D'Souza, Taghian, Lamb, \& Peretiatkos, 2006; Tilikidou, 2007; Dwyer, 2009; Lee, 2009).

Nugrahadi (2002) mengemukakan produk hijau adalah produk yang berwawasan lingkungan yang dirancang dan diproses dengan suatu cara untuk mengurangi efek-efek yang dapat mencemari lingkungan, baik dalam produksi, pendistribusian dan pengonsumsiannya. Selanjutnya Herri, Putri, dan Kenedi (2006) mendefinisikan produk hijau adalah produk yang tidak berbahaya bagi manusia dan lingkungannya, tidak boros sumber daya, tidak menghasilkan sampah berlebihan. Produk hijau biasanya tahan lama, tidak beracun, terbuat dari bahan yang bisa didaur ulang (Ottman, Stafford, \& Hartman, 2006).

Produk hijau bisa diperoleh pada berbagai jenis barang, seperti produk makanan, elektronik, dan kosmetik. Produk hijau seharusnya mendapat respon positif dari masyarakat karena berbagai manfaat yang diberikan, termasuk manfaat terhadap lingkungan. Akan tetapi, permintaan terhadap produk hijau belumlah maksimal. Hal ini ditunjukkan oleh pasar dari produk kosmetik ramah lingkungan di Indonesia belumlah mencapai jumlah yang signifikan.

Salah satu produk kosmetik hijau yang ditawarkan untuk konsumen Indonesia adalah produk kosmetik dengan merek "The Body Shop." "The Body Shop" merupakan salah satu produk yang memiliki brand image yang kuat di Indonesia dibandingkan merek produk kosmetik ramah lingkungan lainnya tetapi keputusan membeli produk "The Body Shop" masih relatif rendah. Niat beli konsumen terhadap produk hijau yang masih rendah ditentukan oleh banyak faktor, antara lain: belum adanya kesadaran terhadap lingkungan, belum adanya kepedulian pada lingkungan, sikap terhadap lingkungan yang tidak positif, belum adanya pengetahuan konsumen tentang produk hijau dan nilai yang dirasakan konsumen serta kepercayaan konsumen pada produk hijau masih relatif rendah.

Kesadaran lingkungan konsumen yang rendah menyebabkan niat beli pada produk hijau juga rendah (Tilikidou, 2007; Albayrak, Aksoy, \& Caber, 2013). Selain itu ada juga beberapa peneliti menyatakan bah- wa kesadaran lingkungan berpengaruh positif dan signifikan terhadap perilaku pembelian produk hijau (Mostafa, 2007; Akehurst, Afonso, \& Goncalves, 2012), tetapi di pihak lain, ada juga peneliti yang menunjukkan hasil sebaliknya, yaitu kesadaran lingkungan tidak mampu meningkatkan perilaku pembelian produk hijau (Bamberg, 2003). Oleh karena itu, penelitian ini perlu dilakukan karena masih adanya kontradiktif hasil penelitian sebelumnya tentang pengaruh kesadaran lingkungan terhadap niat dan perilaku pembelian. Pada penelitian ini akan dilengkapi dengan variabel pemediasi, yaitu variabel sikap pada lingkungan.

Ada beberapa alasan memasukkan variabel sikap sebagai pemediasi, yaitu: 1) menurut teori Theory Plan Behaviour (Ajzen, 1991), sikap merupakan faktor yang mendorong niat dan perilaku pembelian suatu produk; 2) dengan memiliki sikap positif, konsumen pada umumnya akan meningkatkan niat belinya; 3) dari beberapa kajian empiris yang ada (Mostafa, 2007; Teng, 2009; Oliver \& Lee, 2010) variabel sikap mampu meningkatkan niat beli.

Perilaku konsumen ramah lingkungan dicirikan melalui sikap-sikap dan aksi-aksi untuk melindungi lingkungan (Ali, 2013). Menurut Oliver dan Lee, (2010), sikap (attittudes) konsumen adalah faktor penting yang akan mempengaruhi keputusan konsumen untuk membeli suatu produk. Konsep sikap terkait pada konsep kepercayaan dan perilaku. Konsumen biasanya memiliki kepercayaan terhadap atribut suatu produk yaitu, image yang melekat dalam produk. Terbentuknya sikap konsumen akan membentuk niat seseorang untuk melakukan atau tidak melakukan suatu tindakan dan niat tersebut akan mempengaruhi terbentuknya perilaku konsumen. Hal ini menunjukan bahwa jika konsumen memperlihatkan sikap yang positif terhadap isu-isu lingkungan, maka konsumen tersebut akan meningkatkan niatnya untuk membeli produk yang memperhatikan pelestarian lingkungan (Albayrak et al., 2013).

Hasil penelitian sebelumnya yang dilakukan oleh Ishawini (2011), menunjukkan bahwa kesadaran lingkungan secara keseluruhan berkaitan dengan pembelian produk hijau. Arttachariya (2012) juga menyatakan bahwa kesadaran lingkungan dan sikap lingkungan memiliki hubungan positif dengan pembelian produk hijau. Penelitian sebelumnya dilakukan oleh Paladino dan Baggiere (2008) menunjukkan hasil bahwa sikap konsumen mampu memediasi hubungan antara kesadaran lingkungan dengan perilaku pembelian hijau.

Berdasarkan latar belakang masalah yang ada, maka tujuan penelitian ini adalah untuk mengetahui peran sikap dalam memediasi hubungan antara 
kesadaran lingkungan dengan niat beli produk kosmetik ramah lingkungan merek "The Body Shop" di kota Denpasar.

\section{Kesadaran Lingkungan}

Kesadaran lingkungan adalah usaha yang melibatkan setiap warga negara dalam menumbuhkan dan membina kesadaran untuk melestarikan lingkungan berdasarkan tata nilai, yaitu tata nilai dari lingkungan itu sendiri dengan filsafat hidup secara damai dengan alam lingkungannya (Neoloka, 2008, p. 19). Dasar penyebab kesadaran lingkungan adalah etika lingkungan. Etika lingkungan yang sampai saat ini berlaku adalah etika lingkungan yang didasarkan pada sistem nilai yang mendudukkan manusia bukan bagian dari alam, tetapi manusia sebagai penakluk dan pengatur alam. Di dalam pendidikan lingkungan hidup, konsep mental tentang manusia sebagai penakluk alam perlu diubah menjadi manusia sebagai bagian dari alam (Neoloka, 2008, p. 18). Menurut Albayrak et al. (2013) dalam penelitiannya mengukur kepedulian atau kesadaran pada lingkungan diukur dari tiga dimensi, terdiri atas kepedulian egoistic, kepedulian altruistic dan kepedulian biosperic.

\section{Sikap}

Sikap adalah suatu ekspresi yang merefleksikan perasaan ketidaksukaan atau kesukaan seseorang terhadap suatu objek. Pihak perusahaan harus mengetahui sikap konsumen dalam pengambilan keputusan membeli karena sikap seseorang merupakan hasil dari suatu proses psikologis, maka hal itu tidak bisa diamati secara langsung tetapi harus disimpulkan dari apa yang dikatakan atau dilakukannya (Suprapti, 2010 , p. 135). Oleh karena ada keinginan untuk memahami hubungan antara sikap dan perilaku, para psikolog telah membangun beberapa model yang mendasari sikap. Beberapa model sikap yang penting antara lain adalah model sikap tiga komponen (tricomponent attitude model), model sikap multi atribut (multiattribute attitude model), model mencoba mengonsumsi (trying to consume model) dan model sikap terhadap iklan (attitude-toward-the ad-model).

\section{Niat Beli}

Sebelum seseorang melakukan tindakan menggunakan produk atau jasa, ada suatu sikap, yaitu aktivitas mental yang mendahuluinya dan dikenal dengan niat. Niat bisa datang dari dalam diri konsumen itu sendiri. Konsumen dapat memutuskan kapan ia akan menggunakan dan membeli produk tersebut. Se- lain itu, niat bisa datang dari rangsangan luar yaitu datang dari pengaruh orang-orang sekitar yang menggunakan suatu produk tertentu. Niat membeli produk hijau dalam penelitian ini didefinisikan sebagai keinginan, rencana dan kemungkinan pelanggan untuk membeli produk hijau (Wang \& Yu, 2007). Barr (2007) menyatakan niat beli adalah keinginan untuk memiliki produk, niat beli akan timbul apabila seorang konsumen sudah terpengaruh terhadap mutu dan kualitas dari suatu produk, informasi seputar produk. $\mathrm{Ng}$ dan Paladino (2009) menyatakan niat beli didefinisikan sebagai ukuran relatif yang bertujuan untuk melaksanakan perilaku tertentu. Niat adalah kecenderungan untuk melakukan tindakan terhadap objek. Niat dianggap sebagai sebuah "penangkap" atau perantara antara faktor-faktor motivasional yang mempengaruhi perilaku. Niat juga mengindikasikan seberapa keras seseorang mempunyai kemauan untuk mencoba. Niat menunjukkan seberapa banyak upaya yang direncanakan seseorang untuk melakukan sesuatu yang berhubungan dengan perilaku selanjutnya.

Niat untuk membeli produk ramah lingkungan adalah kehendak mengekspresikan niat seorang individu untuk melakukan kegiatan yang mendukung gerakan ekologi (Chan, 1999). Niat berkaitan dengan keinginan terhadap suatu hal yang biasanya diikuti oleh tingkah laku mendukung keinginan tersebut. Dalam proses pengambilan keputusan, niat beli menjadi salah satu bagian terjadinya hal tersebut.

\section{Hipotesis Penelitian}

\section{Hubungan Kesadaran Lingkungan dengan Sikap Konsumen Produk Ramah Lingkungan}

Kesadaran lingkungan yang tertanam pada diri manusia berperan penting terhadap pembentukan sikap yang positif terhadap lingkungan hidup. Seseorang yang memiliki kesadaran lingkungan akan bersikap, dan bertindak ke arah pengolahaan lingkungan yang baik. Seseorang yang memiliki kesadaran lingkungan rendah akan bersikap negatif dan bertindak semena-mena terhadap lingkungan tanpa memperhatikan kaidah-kaidah yang berlaku sehingga proses pengolaan lingkungan berjalan kurang baik. Menurut Cheah dan Phau (2011) terjadinya perubahan sikap merupakan hasil interaksi kompleks berbagai faktor dan salah satu yang ditemukan adalah adanya kesadaran lingkungan yang dimiliki seseorang. Penelitian yang berkaitan dengan kesadaran lingkungan dan sikap pernah dilakukan oleh Bajari (2012), Darmawan, Saam, dan Zulkarnaini (2010) dan Albayrak et al. (2013) yang menunjukkan hasil bahwa kesadaran lingkungan berpengaruh positif dan signifi- 
kan terhadap sikap konsumen. Berdasarkan beberapa kajian empiris tersebut, dapat disusun hipotesis sebagai berikut:

$H_{l}$ : Kesadaran lingkungan memiliki hubungan positif dengan sikap konsumen produk ramah lingkungan.

Hubungan Kesadaran Lingkungan dengan Niat Beli Produk Ramah Lingkungan

Menurut Ardianti et al. (2008) kesadaran lingkungan yang relatif rendah terhadap produk kosmetik ramah lingkungan mengakibatkan rendahnya pengetahuan konsumen akan produk kosmetik ramah lingkungan, sehingga menyebabkan afeksi atau perasaan menyukai terhadap produk kosmetik ramah lingkungan juga relatif rendah yang pada akhirnya mengakibatkan niat pembelian serta perilaku pembelian terhadap produk kosmetik ramah lingkungan juga relatif rendah, begitu pula sebaliknya kesadaran lingkungan yang tinggi akan produk kosmetik ramah lingkungan akan mengakibatkan niat pembelian serta perilaku pembelian produk ramah lingkungan yang relatif tinggi. Selain itu, penelitian yang dilakukan oleh Junaedi (2005) dan Ishawini (2011), juga menunjukkan hasil bahwa kesadaran lingkungan berpengaruh positif terhadap niat beli produk hijau. Berdasarkan beberapa hasil kajian empiris tersebut, dapat dibangun hipotesis sebagai berikut:

$\mathrm{H}_{2}$ : Kesadaran lingkungan memiliki hubungan positif dengan niat beli produk ramah lingkungan.

\section{Hubungan Sikap dengan Niat Beli Produk Ramah Lingkungan}

Menurut Pradipta, Surya, dan Suprapti (2013), sikap merupakan suatu ekspresi seseorang yang merefleksikan rasa suka atau tidak suka terhadap suatu objek. Umumnya semakin positif sikap, semakin kuat niat untuk melakukan perilaku pembelian dan sebaliknya (Aman, Harun, \& Hussein, 2012). Para pemasar meyakini bahwa sikap positif yang ditunjukkan oleh konsumen terhadap sebuah objek akan memudahkan untuk memacu perilaku positif terhadap objek tersebut. Penelitian sebelumnya juga dilakukan oleh Arttachariya (2012), Chen dan Leu (2010) dan Aman et al. (2012) menunjukkan hasil bahwa terdapat hubungan yang positif dan signifikan antara sikap konsumen pada lingkungan dengan niat pembelian pada produk hijau. Hasil penelitian ini juga sesuai dengan pendapat dari Chen dan Chang (2012); Zhou, Thøgersen, Ruan, \& Guang (2013). Berdasarkan kajian empiris tersebut, dapat disusun hipotesis sebagai berikut:
$H_{3}$ : Sikap memiliki hubungan positif dengan niat beli produk kosmetik ramah lingkungan.

Peran Sikap Memediasi Hubungan Kesadaran Lingkungan dengan Niat Beli Produk Ramah Lingkungan

Yeoh dan Paladino (2008) menemukan bahwa sikap hanya sebagian memediasi hubungan antara pengetahuan lingkungan dan perilaku pembelian hijau. Namun, mereka menemukan adanya efek mediasi penuh dari sikap pada hubungan antara kepedulian lingkungan dengan perilaku pembelian produk hijau. Paladino dan Baggiere (2008) dalam penelitiannya mengatakan bahwa sikap mampu memediasi secara penuh hubungan antara kesadaran lingkungan dengan perilaku pembelian hijau. Penelitian lainnya dilakukan oleh Aman et al. (2012) yang meneliti tentang hubungan pengetahuan lingkungan, kesadaran lingkungan, dan niat beli, dengan peran sikap sebagai mediator menyatakan bahwa sikap tidak memediasi hubungan pengetahuan lingkungan dengan niat pembelian, namun sikap memediasi penuh hubungan kepedulian lingkungan dengan niat pembelian. Berbasis pada hasil kajian empiris tersebut dibangun hipotesis sebagai berikut:

$H_{4}$ : Sikap mampu memediasi hubungan kesadaran lingkungan dengan niat beli produk ramah lingkungan.

\section{Metode Penelitian}

Penelitian ini menggunakan metode asosiatif. Penelitian asosiatif menurut Sugiyono (2013, p. 55) adalah dugaan tentang adanya hubungan antar variabel dalam populasi yang diuji. Berdasarkan pengertian tersebut, maka hubungan yang diteliti adalah hubungan variabel kesadaran lingkungan dengan niat beli yang dimediasi oleh sikap. Lokasi penelitian ini dilakukan di kota Denpasar. Objek yang akan diteliti dalam penelitian ini adalah hubungan kesadaran lingkungan dengan niat beli, hubungan kesadaran lingkungan dengan sikap, hubungan sikap dengan niat beli, dan peran sikap sebagai pemediasi. Pada penelitian ini, klasifikasi variabel adalah sebagai berikut: variabel eksogen adalah kesadaran lingkungan, variabel mediasi adalah sikap pada lingkungan, dan variabel endogen adalah niat beli produk ramah lingkungan.

Dalam penelitian ini, yang menjadi populasi adalah seluruh konsumen yang telah yang memiliki niat beli produk kosmetik ramah lingkungan. Pengambilan sampel dilakukan dengan teknik purposive sampling. Dalam penelitian ini jumlah sampel yang digunakan adalah sebanyak 105 responden. Skala pe- 
ngukuran yang digunakan dalam penelitian ini menggunakan skala Likert dengan lima tingkatan. Teknik analisis data yang digunakan adalah Structural Equation Modelling (SEM). Selain itu juga dilengkapi dengan Uji Sobel untuk mengetahui peran sikap sebagai variabel pemediasi.

\section{Hasil Penelitian dan Pembahasan}

\section{Karakteristik Responden}

Responden dalam penelitian ini berjumlah 105 orang sesuai dengan ukuran sampel yang digunakan. Responden penelitian digambarkan dengan menyajikan karakteristiknya berdasarkan jenis kelamin, usia, dan tingkat pendidikan. Secara rinci dapat dilihat pada Tabel 1.

Tabel 1

Karakteristik Responden

\begin{tabular}{cccc}
\hline Variabel & Klasifikasi & $\begin{array}{c}\text { Jumlah } \\
\text { (orang) }\end{array}$ & Persentase \\
\hline Jenis Kelamin & Perempuan & 93 & 88,57 \\
& Laki-laki & 12 & 11,43 \\
Usia (tahun) & $\leq 20$ & 16 & 15,24 \\
& $21-35$ & 33 & 31,43 \\
& $36-50$ & 39 & 37,14 \\
Pendidikan & $51-65$ & 17 & 16,19 \\
& SMA & 47 & 44,76 \\
& Diploma & 22 & 20,95 \\
& Sarjana & 36 & 34,29 \\
\hline
\end{tabular}

Berdasarkan klasifikasi jenis kelamin, responden di dominasi oleh perempuan sebanyak 88,57 persen, sedangkan laki-laki sebanyak 11,43 persen. Berdasarkan klasifikasi usia hasil penelitian ini menunjukkan bahwa responden berusia $\leq 20$ tahun yaitu sebesar 15,24 persen, responden berusia 21-35 tahun yaitu sebesar 31,43 persen, responden berusia 36-50 tahun yaitu sebesar 37,14 persen, serta yang terakhir berusia 51-65 yaitu sebesar 16,19 persen. Berdasarkan klasifikasi terakhir yaitu tingkat pendidikan yang didominasi oleh responden yang memiliki pendidikan SMA sebesar 44,76 persen, kemudian yang berpendidikan Sarjana sebesar 34,29 persen, dan yang paling sedikit berpendidikan Diploma sebesar 20,95 persen.

\section{Uji Validitas Dan Reliabilitas}

Pengujian validitas tiap butir pernyataan dalam instrumen penelitian menggunakan analisis item yaitu korelasi skor tiap item dengan skor total item. Nilai korelasi antar skor item dengan total item kemudian dibandingkan dengan $r_{\text {kritis. }}$. Jika korelasi item terha- dap skor total lebih besar dari $r_{\text {kritis }}(0,30)$ maka instrumen dikatakan valid. Uji reliabilitas dilakukan terhadap instrumen dengan koefisien Cronbach'c Alpha. Suatu instrumen dikatakan reliable apabila nilai Cronbach's Alpha lebih besar dari 0,60 maka instrumen yang digunakan reliable. Hasil uji validitas dan reliabilitas instrumen penelitian disajikan pada Tabel 2.

Tabel 2

Hasil Uji Validitas dan Reliabilitas

\begin{tabular}{|c|c|c|c|}
\hline Variabel & Item & Korelasi $R$ & $\begin{array}{l}\text { Cronbach's } \\
\text { Alpha } \alpha\end{array}$ \\
\hline Kesadaran & $X_{1.1}$ & 0,868 & 0,942 \\
\hline & $\begin{array}{l}X_{1.2} \\
X_{1.3} \\
X_{1.4} \\
X_{1.5} \\
X_{1.6} \\
X_{1.7} \\
X_{1.8} \\
X_{1.9} \\
\end{array}$ & $\begin{array}{l}0,875 \\
0,752 \\
0,829 \\
0,840 \\
0,704 \\
0,886 \\
0,901 \\
0,790 \\
\end{array}$ & \\
\hline $\begin{array}{l}\text { Sikap Pada } \\
\text { Lingkungan }\left(Y_{l}\right)\end{array}$ & $\begin{array}{l}Y_{1.1} \\
Y_{1.2} \\
Y_{1.3} \\
Y_{1.4}\end{array}$ & $\begin{array}{l}0,861 \\
0,911 \\
0,843 \\
\end{array}$ & 0,883 \\
\hline Niat Beli $\left(Y_{2}\right)$ & $\begin{array}{l}Y_{2.1} \\
Y_{2.2} \\
Y_{2.3} \\
Y_{2.4} \\
Y_{2.5} \\
Y_{2.6} \\
Y_{2.7} \\
Y_{2.8}\end{array}$ & $\begin{array}{l}0,872 \\
0,851 \\
0,892 \\
0,867 \\
0,790 \\
0,860 \\
0,915 \\
0,795 \\
\end{array}$ & 0,947 \\
\hline
\end{tabular}

Berdasarkan Tabel 2 diketahui bahwa korelasi $\left(r_{\text {hitung }}\right)$ antar skor instrumen dengan skor total seluruh item pernyataan lebih besar dari $r_{\text {tabel }}(0,349)$. Jadi seluruh item instrumen dapat dinyatakan layak digunakan sebagai alat ukur. Tabel 2 juga menunjukkan bahwa nilai Cronbach's Alpha untuk setiap variabel lebih besar dari 0,60. Jadi dapat dinyatakan bahwa seluruh variabel telah memenuhi syarat reliabilitas atau kehandalan.

\section{Hasil Analisis Data}

\section{Pengujian Model Struktural (Inner Model)}

Inner model menggambarkan hubungan antar variabel laten berdasarkan pada substantive theory. Dalam menilai model dengan PLS, dimulai dengan melihat $R$-squares untuk setiap variabel laten de- 
penden. Hasil pengujian inner model dapa melihat hubungan antar konstruk dengan dengan cara membandingkan nilai signifikansi dan $R$-square dari model penelitian (Ghozali, 2012, p. 42).

Tabel 3

Nilai $R$-Squares

\begin{tabular}{lc}
\hline \multicolumn{1}{c}{ Variabel } & R Square \\
\hline Kesadaran Lingkungan & \\
Niat Beli & 0,824 \\
Sikap & 0,717 \\
\hline
\end{tabular}

Nilai $R$-square variabel niat beli sebesar 0,824 pada Tabel 3 dapat diintepretasikan bahwa $82,4 \%$ variabilitas konstruk niat beli dijelaskan oleh variabel kesadaran lingkungan dan sikap, sedangkan $71,7 \%$ variabel sikap dijelaskan oleh variabel kesadaran lingkungan, dan 0,419 variabel niat beli disebabkan oleh variabel di luar model.

Model struktural tersebut disebut model refleksif yang mana covariance pengukuran indikator dipengaruhi oleh konstruk laten atau mencerminkan variasi dari konstruk unidimensional yang digambarkan dengan bentuk elips dengan beberapa anak panah dari konstruk ke indikator. Model ini menghipotesiskan bahwa perubahan pada konstruk laten akan mempengaruhi perubahan pada indikator.

Dalam model tersebut terdapat satu variabel eksogen yaitu variabel kesadaran lingkungan dan dua variabel endogen yaitu sikap dan niat beli. Ketiga variabel tersebut memiliki indikator masing-masing.

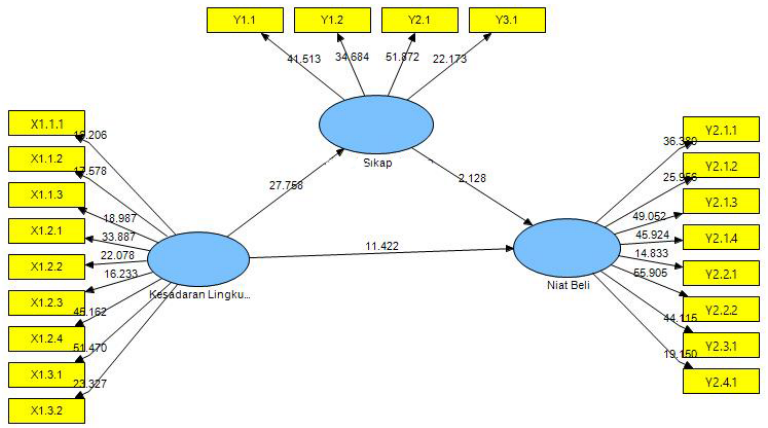

Gambar 1. Diagram Jalur Hasil Uji Hipotesis

\section{Pengujian Hipotesis}

Tabel 4

Result for Inner Loadings

\begin{tabular}{lcc}
\hline & $\begin{array}{c}\text { Original } \\
\text { Sample }\end{array}$ & T-Statistics \\
& $(\mathrm{O})$ & \\
\hline Kesadaran Lingkungan --- > Niat Beli & 0,784 & 11,422 \\
Kesadaran Lingkungan --- > Sikap & 0,847 & 27,758 \\
Sikap --- > Niat Beli & 0,142 & 2,128 \\
\hline
\end{tabular}

Pengujian terhadap hipotesis dalam metode PLS dilakukan dengan menggunakan simulasi terhadap setiap hubungan yang dihipotesiskan, dalam hal ini dilakukan metode bootstrap terhadap sampel. Metode bootstrap juga berfungsi untuk meminimalkan masalah ketidaknormalan data penelitian yang digunakan. Pada penelitian ini telah ditentukan sebelumnya nilai $t$-tabel dengan signifikansi $5 \%, d k=102$, adalah sebesar 1,984. Hasil pengujian hipotesis dengan bootstrapping dari analisis PLS adalah sebagai berikut:

Pengujian : Hubungan kesadaran lingkungan Hipotesis 1 dengan sikap konsumen produk kosmetik ramah lingkungan

Hasil pengujian hipotesis pertama menunjukkan bahwa hubungan kesadaran lingkungan dengan sikap menunjukkan nilai koefisien jalur sebesar 0,847 dengan nilai $t$-statistik sebesar 27,758 . Nilai $t$-statistik tersebut lebih besar dari nilai t-tabel sebesar 1,984 menunjukkan bahwa ada hubungan yang signifikan antara variabel kesadaran lingkungan dengan sikap. Koefisien jalurnya menunjukkan bahwa kesadaran lingkungan memberikan pengaruh positif terhadap sikap konsumen, artinya bahwa semakin sadar konsumen akan lingkungan maka akan membentuk sikap yang positif pada lingkungan. Hal ini berarti Hipotesis 1 diterima.

Pengujian : Hubungan kesadaran lingkungan deHipotesis 2 ngan niat beli produk kosmetik ramah lingkungan

Hasil pengujian hipotesis kedua menunjukkan bahwa hubungan kesadaran lingkungan dengan niat beli menunjukkan nilai koefisien jalur sebesar 0,784 dengan nilai $t$-statistik sebesar 11,422. Nilai $t$-statistik tersebut lebih besar dari nilai t-tabel sebesar 1,984 menunjukkan bahwa ada hubungan yang signifikan antara variabel kesadaran lingkungan dengan niat beli. Koefisen jalurnya menunjukkan bahwa kesadaran lingkungan memberikan pengaruh positif terhadap niat beli, artinya bahwa semakin sadar masyarakat pada lingkungan, maka niat beli produk kosmetik ramah lingkungan juga semakin tinggi. Hal ini berarti Hipotesis 2 diterima.

Pengujian : Hubungan niat dengan niat beli proHipotesis 3 duk kosmetik ramah lingkungan

Hasil pengujian hipotesis ketiga menunjukkan bahwa hubungan sikap dengan niat beli menunjukkan nilai koefisien jalur sebesar dengan nilai $t$-statistik sebesar 2,128. Nilai $t$-statistik tersebut lebih besar dari nilai t-tabel sebesar 1,984 menunjukkan bahwa ada hubungan yang signifikan antara variabel sikap dengan niat beli. Koefisien jalurnya menunjukkan bah- 
wa sikap memberikan pengaruh positif terhadap niat beli, artinya bahwa semakin positif sikap masyarakat terhadap produk kosmetik ramah lingkungan, maka niat beli produk kosmetik ramah lingkungan juga semakin tinggi. Hal ini berarti Hipotesis 3 diterima.

Pengujian : Sikap memediasi hubungan kesadaran Hipotesis 4 lingkungan dengan niat beli produk kosmetik ramah lingkungan

Hasil analisis data pada hipotesis keempat menggunakan uji Sobel. Uji Sobel merupakan alat analisis untuk menguji signifikansi dari hubungan tidak langsung antara variabel independen dengan variabel dependen yang dimediasi oleh variabel mediator. Bila hasil kalkulasi $Z$ lebih besar dari 1,96 maka variabel mediator dinilai secara signifikan memediasi hubungan antara variabel independen dengan variabel dependen.

$$
\mathrm{Sab}=\sqrt{\mathrm{b}^{2} \mathrm{~S}_{\mathrm{a}}^{2}+\mathrm{a}^{2} \mathrm{Sb}^{2}+\mathrm{S}_{\mathrm{a}}^{2}} \mathrm{Sb}^{2}
$$

Keterangan:

$a=0,847$
$S a=0,030$
$b=0,142$
$S b=0,066$

Diperoleh $S_{a b}=0,561$

$$
\begin{aligned}
& Z=\frac{a b}{\sqrt{b^{2} S_{a}^{2}+a^{2} S_{b}^{2}+S_{a}^{2} S_{b}^{2}}} \\
& Z \quad=\frac{a b}{S_{a b}}=\frac{(0,847)(0,142)}{0,561}=0,214 \\
& Z_{\text {tabel }}=1,96(5 \%)
\end{aligned}
$$

Berdasarkan hasil Uji Sobel menunjukkan bahwa hasil kalkulasi $Z=0,214$. Hasil kalkulasi $Z=0,214<1,96$ ini berarti variabel sikap tidak secara signifikan memediasi hubungan antara kesadaran lingkungan dengan niat beli. Hal ini berarti Hipotesis 4 ditolak.

\section{Pembahasan}

Hubungan Kesadaran Lingkungan dengan Sikap Konsumen

Hasil pengujian hipotesis menunjukkan nilai $t$ statistik sebesar 2,128 lebih besar dari nilai $t$-tabel sebesar 1,984 yang menunjukkan bahwa ada hubungan yang signifikan antara variabel sikap dengan niat beli. Jadi hasil penelitian ini sejalan atau mendukung hasil penelitian sebelumnya yang dilakukan oleh Darmawan et al. (2010) dan Bajari (2012), menyatakan bah- wa terdapat hubungan positif antara kesadaran lingkungan dengan sikap terhadap lingkungan. Artinya, semakin tinggi kesadaran lingkungan, maka sikap konsumen pada lingkungan hidup juga semakin tinggi.

\section{Hubungan Kesadaran Lingkungan dengan Niat Beli Produk Ramah Lingkungan}

Hasil pengujian hipotesis menunjukkan nilai $t$ statistik sebesar 11,422 lebih besar dari nilai t-tabel sebesar 1,984, hal ini menunjukkan bahwa ada hubungan yang signifikan antara variabel kesadaran lingkungan dengan niat beli. Penelitian ini sesuai dengan penelitian sebelumnya yang dilakukan oleh Junaedi (2005) dan Ishawini (2011) yang menyatakan bahwa kesadaran lingkungan secara keseluruhan berpengaruh terhadap niat beli produk hijau dalam konteks perilaku pembelian umum mereka.

\section{Hubungan Sikap Konsumen dengan Niat Beli Produk Kosmetik Ramah Lingkungan}

Hasil pengujian hipotesis menunjukkan nilai koefisien jalur dengan nilai $t$-statistik sebesar 2,128 lebih besar dari nilai t-tabel sebesar 1,984 menunjukkan bahwa ada hubungan yang signifikan antara variabel sikap dengan niat beli. Hasil penelitian ini sejalan dengan hasil penelitian dari Mostafa (2007) dan Teng (2009) menemukan bahwa sikap dan norma subjektif merupakan dua komponen yang signifikan mempengaruhi niat konsumen. Penemuan lainnya juga dilakukan oleh Chen dan Leu (2010) dan Aman et al. (2012) bahwa terdapat pengaruh signifikan antara sikap konsumen pada lingkungan terhadap niat pembelian pada produk hijau. Selain itu juga, penelitian ini sesuai dengan hasil penelitian dari Khare (2014), yang menunjukkan hasil bahwa sikap positif pada produk hijau meningkatkan niat untuk membeli produk hijau.

\section{Sikap Memediasi Hubungan Kesadaran Lingkungan} dengan Niat Beli Produk Ramah Lingkungan

Hasil analisis data pada hipotesis keempat menggunakan uji Sobel. Berdasarkan hasil uji Sobel menunjukkan bahwa hasil kalkulasi $Z=0,214$. Hasil kalkulasi $Z=0,214<1,96$ ini berarti variabel sikap tidak signifikan memediasi hubungan antara kesadaran lingkungan dengan niat beli. Hal ini memiliki makna bahwa hubungan kesadaran lingkungan dengan niat beli konsumen pada produk ramah lingkungan tidak hanya didorong karena adanya sikap positif semata, tetapi masih ada variabel lain yang mempengaruhi, seperti dorongan teman/keluarga, daya beli, dan harga produk. Yeoh dan Paladino (2008) 
menemukan bahwa sikap hanya sebagian memediasi hubungan antara pengetahuan lingkungan dan perilaku pembelian hijau. Namun, mereka menemukan adanya efek mediasi yang penuh oleh sikap pada hubungan antara kepedulian lingkungan dengan perilaku pembelian produk hijau. Paladino dan Baggiere (2008) dalam penelitiannya mengatakan bahwa sikap memediasi secara penuh hubungan antara kesadaran lingkungan dan perilaku pembelian hijau. Jadi hasil penelitian ini tidak sejalan dengan penelitian Paladino dan Baggiere (2008).

\section{Simpulan dan Implikasi}

Berdasarkan hasil penelitian dan pembahasan, maka dapat ditarik simpulan sebagai berikut: 1) Semakin tinggi kesadaran lingkungan, maka semakin positif sikap konsumen pada produk kosmetik ramah lingkungan merek "The Body Shop." 2) Konsumen yang memiliki kesadaran lingkungan yang tinggi dapat meningkatkan niat beli konsumen pada produk kosmetik ramah lingkungan merek "The Body Shop." 3) Sikap positif yang ditunjukkan oleh konsumen terhadap produk kosmetik ramah lingkungan merek "The Body Shop" dapat memperkuat niat pembelian mereka pada kosmetik ramah lingkungan merek "The Body Shop." 4) Sikap tidak signifikan dalam memediasi hubungan kesadaran lingkungan dengan niat beli, artinya sikap tidak mampu memperkuat hubungan antara kesadaran lingkungan dengan niat beli.

Hasil penelitian ini memiliki beberapa implikasi sebagai berikut: 1) Bagi bisnis "The Body Shop, " upaya pengenalan kembali kepada konsumen atau masyarakat bahwa The Body Shop sebagai produk yang memperhatikan lingkungan dan memiliki tanggung jawab sosial adalah penting karena kesadaran dan sikap konsumen terhadap produk ramah lingkungan semakin tinggi. 2) Bagi peneliti selanjutnya dapat mempertimbangkan variabel lain yang berhubungan dengan niat beli seperti pengetahuan lingkungan, persepsi nilai konsumen, dan kepercayaan pada produk hijau sebagai variabel pemediasi.

\section{Daftar Referensi}

Akehurst, G., Afonso, C., \& Goncalves, H. M. (2012). Re-examining green purchase behavior and the green consumer profile: New evidence. Management Decision, 50(5), 972-988.

Albayrak, T., Aksoy, S., \& Caber, M. (2013). The effect of environmental concern and scepticism on green purchase behavior. Marketing Intelligence \& Planning, 31(1), 27-39.
Ali, S. (2013). Prediksi perilaku ramah lingkungan yang dipengaruhi oleh nilai dan gaya hidup konsumen. Jurnal Perspektif Bisnis, 1(1), 112125.

Aman, A. H. L., Harun, A., \& Hussein, Z. (2012). The influence of environmental knowledge and concern on green purchase intention the role of attitude as a mediating variable. British Journal of Arts and Social Sciences, 7(2), 145-167.

Ardianti, N. T., Fahmi, I., \& Ratnawati, A. (2008). Analisis perilaku konsumen bogor terhadap produk kosmetik hijau. Jurnal Manajemen \& Agribisnis, 5 (1), 16-22.

Arttachariya, P. (2012). Environmentalism and green purchasing behavior: A study on graduate students in Bangkok, Thailand. Diunduh 1 Maret 2015 dari http://www.bu.ac.th/knowledgecenter/ epaper/july_dec2012/pdf/ac01.pdf.

Ajzen, I. (1991). The theory of planned behavior. Organizational Behaviour and Human Decision Processes, 50(2), 179-211.

Bajari, R. R. (2012). Pengaruh sikap, norma subjektif dan kendali perilaku terhadap kesadaran dan perilaku ramah lingkungan pada tenaga kesehatan di rumah sakit Fakultas Farmasi Universitas Padjajaran Jatinangor. Journal of Environmental Science, 2(4), 103-116.

Barr, S. (2007). Factors influencing environmental attitudes and behaviors. Environment and Behavior, 39(4), 435-473.

Bamberg, S. (2003). How does environmental concern influence specific environmentally related behaviours? A new answer to an old question. Journal of Environmental Psychology, 23(1), 21-32.

Chan, R. (1999) Environmental attitudes and behaviors of consumers in China: Survey findings and implications. Journal of International Consumer Marketing, 11(4), 25-52.

Cheah, I. \& Phau, I. (2011) Attitudes towards environmentally friendly products: The influence of ecoliteracy, interpersonal influence, and value orientation. Marketing Intelligence \& Planning, 29(5), 452-472.

Chen, T. B. \& Leu, T. C. (2010). Towards the environment and green products. Management Science and Engineering, 4(2), 27-39.

Chen, Y. S. (2011). Green organizational identity: Sources and consequence. Management Decision, 49(3), 384-404.

Chen, Y. S. \& Chang, C. H. (2012). Enhance green purchase intentions: The roles of green perceived value, green perceived risk, and green trust. Management Decision, 50(3), 502-520. 
Darmawan, B., Saam, Z., \& Zulkarnaini. (2010). Hubungan pengetahuan, sikap, perilaku dan peran serta dengan kesadaran lingkungan hidup serta kesanggupan membayar masyarakat sekitar bantaran sungai di kota Pekanbaru. Jurnal of Environmental Science, 2(4), 103-106.

D’Souza, C., Taghian, M., Lamb, P., \& Peretiatkos, R. (2006). Green products and corporate strategy: An empirical investigation. Society and Business Review, 1(2), 144-157.

Dwyer, R. J. (2009). Keen to be green organizations: A focused rules approach to accountability. $\mathrm{Ma}$ nagement Decision, 47(7), 1200-1216.

Ghozali, I. (2012). Aplikasi analisis multivariate dengan program IBM SPSS 20. Semarang: Badan Penerbit Universitas Diponegoro.

Harris, P. G. (2006). Environmental perspectives and behavior in China: Synopsis and bibliography. Environment and Behavior, 38(1), 5-21.

Herri, Putri, N., \& Kenedi, J. (2006). Analisis persepsi masyarakat terhadap produk hijau: Tinjauan faktor demografi, psikologi, sosial, dan budaya (kasus kota Padang). Jurnal Business \& Manajemen, 2(1).

Ishawini. (2011). Pro-environmental concern influencing green buying: A study on Indian consumers. Management Science and Engine International Journal of Business and Management, 6 (6), 124-133.

Junaedi, S. M. F. (2005). Pengaruh kesadaran lingkungan pada niat beli produk hijau: Studi perilaku konsumen berwawasan lingkungan. Jurnal Manajemen dan Bisnis, 9(2), 189-201.

Khare, A. (2014). Consumers' susceptibility to interpersonal influence as a determining factor of ecologically conscious behavior. Marketing Intelligence \& Planning, 32(1), 2-20.

Lee, K. H. (2009). Why and how to adopt green management into business organizations? The case study of Korean SMEs in manufacturing industry. Management Decision, 47(7), 1101-1121.

Mostafa, M. M. (2007). A hierarchical analysis of the green consciousness of the Egyptian consumer. Psychology \& Marketing, 24(5), 445-473.

Nugrahadi, E. W. (2002). Pertanian organik sebagai alternatif teknologi dalam upaya menghasilkan produk hijau. Bogor: Institut Pertanian Bogor.

Neoloka, A. (2008). Kesadaran lingkungan. Jakarta: PT Rineka Cipta.
Ng, S. \& Paladino, A. (2009). Examining the influences of intention to purchase green mobile phones among young consumers: An empirical analysis. ANZMAC, $1-8$.

Oliver, J. D. \& Lee, S. H. (2010). Hybrid car purchase intentions: A cross-cultural analysis, Journal of Consumer Marketing, 27(2), 96-103.

Ottman, J. A., Stafford, E. R., \& Hartman, C. L. (2006). Avoiding green marketing myopia: Ways to improve consumer appeal for environmentally preferable products. Environment, 48(5), 22-36.

Paladino, A. \& Baggiere, J. (2008). Are we "green”? An empirical investigation of renewable electricity consumption. European Advances in Consumer Research, 18, 340-341.

Pradipta, Surya, I. B. G., \& Suprapti, N, W. (2013). Pengaruh sikap dan norma subyektif terhadap niat calon pemilih di kota Denpasar untuk memilih partai demokrat dalam pemilu legislatif tahun 2014. Jurnal Manajemen, Strategi Bisnis, dan Kewirausahaan, 7(1), 29-39.

Sugiyono. (2013). Metode penelitian bisnis. Bandung: CV Alfabeta.

Suprapti, N. W. S. (2010). Perilaku konsumen: Pemahaman dasar dan aplikasinya dalam strategi pemasaran. Bali: Udayana University Press.

Tilikidou, I. (2007). The effects of knowledge and attitudes upon Greeks' pro-environmental purchasing behaviour. Corporate Social Responsibility and Environmental Management, 14(3), 121-134.

Teng, L. (2009). A comparison of two types of price discounts in shifting consumers' attitude and purchase intentions. Journal of Business Research, 62(1), 14-21.

Wang, Z. \& Yu, H. (2007). A empirical study of purchasing behaviour on green food. Journal of Anhui Agriculture Science, 35(10), 56-58.

Yeoh, M. \& Paladino, A. (2008). Analysing the effects of prestige of environmental attitudes and behaviours upon low-involvement purchase: Does branding matter? Diunduh 1 Maret 2015 dari http://conferences.anzmac.org/ANZMAC2 007/papers/M\%20Yeoh_1a.pdf.

Zhou, Y., Thøgersen, J., Ruan, Y., \& Guang, H. (2013). The moderating role of human values in planned behavior: The case of Chinese consumers' intention to buy organic food. Journal of Consumer Marketing, 30(4), 335 -344. 